\title{
Two Radiocarbon Dates from the Salt Lick Site (16SA37a) at Toledo Bend Reservoir, Sabine Parish, Louisiana
}

Timothy K. Perttula

Heritage Research Center, Stephen F. Austin State University

Follow this and additional works at: https://scholarworks.sfasu.edu/ita

Part of the American Material Culture Commons, Archaeological Anthropology Commons, Environmental Studies Commons, Other American Studies Commons, Other Arts and Humanities Commons, Other History of Art, Architecture, and Archaeology Commons, and the United States History Commons

Tell us how this article helped you.

This Article is brought to you for free and open access by the Center for Regional Heritage Research at SFA ScholarWorks. It has been accepted for inclusion in Index of Texas Archaeology: Open Access Gray Literature from the Lone Star State by an authorized editor of SFA ScholarWorks. For more information, please contact cdsscholarworks@sfasu.edu. 


\section{Two Radiocarbon Dates from the Salt Lick Site (16SA37a) at Toledo Bend Reservoir, Sabine Parish, Louisiana}

\section{Creative Commons License}

\section{(c) (1) (8)}

This work is licensed under a Creative Commons Attribution-NonCommercial 4.0 International License 


\title{
Two Radiocarbon Dates from the Salt Lick Site (16SA37a) at Toledo Bend Reservoir, Sabine Parish, Louisiana
}

\author{
Timothy K. Perttula
}

\section{INTRODUCTION AND SITE CONTEXT}

The Salt Lick site (16SA37) is an ancestral Caddo site at Toledo Bend Reservoir in Sabine Parish, Louisiana. Before the creation of the reservoir, archaeological investigations on the Sabine River and tributaries in both Louisiana and Texas took place primarily took during the 1960s, with survey and excavations, sometimes of a very limited nature (Scurlock and Davis 1962; Scurlock 1964; McClurkan et al. 1966; Jensen 1968a, 1968b; Woodall 1969; Benham et al. 1973) by the University of Texas and Southern Methodist University. The Salt Lick site was investigated by McClurkan et al. (1966) in the Fall of 1964.

The Salt Lick site (16SA37a) was a Caddo habitation site (with midden deposits) on a natural rise south of La Nana bayou, a westward-flowing tributary to the Sabine River. Hand and backhoe trench excavations uncovered 10 burials, six that may have been flexed and four that were extended burials with the deceased placed in an extended supine position on the floor of the grave (McClurkan et al. 1966).

Only two of the flexed burials had funerary offerings: a Pease Brushed-Incised jar and an engraved carinated bowl with a poorly executed design (Burial 1), and two engraved bowls (Burial 4). The engraved bowls resemble varieties of Womack Engraved and Patton Engraved (McClurkan et al. 1966:Figures 21f and 22h). The extended burials, on the other hand, had a number of funerary offerings, including ceramic vessels $(n=25)$, a clay elbow pipe $(n=1)$, a quiver of Perdiz arrow points $(n=12)$, a sandstone ear spool, mussel shells $(\mathrm{n}=2)$, and turtle shells $(\mathrm{n}=3)$.

\section{Radiocarbon Samples and Results from Vessel Organic Residues}

There are currently 22 Caddo ceramic vessels in the Texas Archeological Research Laboratory collections from the Salt Lick site, and organic residue was preserved on two of the vessels from two different extended burials when the collection was recently reanalyzed by Perttula and Walters (2015). Samples of the organic residue was collected from the vessels and submitted to DirectAMS for AMS radiocarbon dating. The 1 and 2 sigma calibrations of the two radiocarbon samples from the Salt Lick site are based on the IntCal13 calibration curve (see Reimer et al. 2013; see also http://intcal.qub.ac.uk/intcal13/) for the Northern Hemisphere).

The first radiocarbon sample from the site is from Vessel 1 in Feature 10, one of the extended burials in the cemetery. This vessel is a short-rimmed and grog-tempered Karnack Brushed-Incised jar. The rim of the vessel is plain, but the vessel body has vertical brushed-incised marks and lines that extend from the rim-body juncture to within $20 \mathrm{~mm}$ of the vessel base. There was organic residue preserved on the vessel body. The conventional age of the organic residue is $441 \pm 22$ B.P. (DirectAMS 008418). At 1 sigma, the calibrated age range is 501-511 years B. P. (A.D. 1439-1449), and at 2 sigma, the calibrated age range is 492-518 years B.P., or A.D. 1432-1458.

The second radiocarbon sample from the Salt Lick site is from a grog-tempered Pease Brushed-Incised jar (Feature 12, Vessel 1) with organic residue on the vessel body. The vessel rim has horizontal brushing marks. The vessel body has five sets of upper and lower broad diagonal incised lines with open nested diamond-shaped spaces. The conventional age of the organic residue on the Pease Brushed-Incised vessel 
is $411 \pm 25$ B.P. (DirectAMS 008419). At 1 sigma, the calibrated age range is $483-504$ years B. P. (A.D. 1446-1467), and at 2 sigma, the calibrated age range is 461-511 years B.P., or A.D. 1439-1489.

\section{SUMMARY AND CONCLUSIONS}

Two AMS radiocarbon dates have been obtained on organic residue preserved on Karnack Brushed-Incised and Pease Brushed-Incised jars from two extended burials at the Salt Lick site at Toledo Bend Reservoir. The vessels are currently curated at the Texas Archeological Research Laboratory, and were recently reexamined by Perttula and Walters (2015). The 2 sigma calibrated age ranges from the organic residue on the vessels are A.D. 1432-1458 and A.D. 1439-1489.

Post-A.D. 1400/1430 Caddo archaeological sites at Toledo Bend Reservoir are included in a Salt Lick phase (Perttula and Walters 2015). The radiocarbon dates reported in this article from the Salt Lick site are the first such dates from a Salt Lick phase component. Recognized decorated types in these sites include Belcher Ridged, Glassell Engraved, Keno Trailed, Mound Tract Incised and Brushed, Pease Brushed-Incised, Pineland Punctated-Incised, Ripley Engraved, and Taylor Engraved. Vessels in our analyzed set (Perttula and Walters 2015) include Karnack Brushed-Incised, Pease Brushed-Incised, Ripley Engraved, and Wilder Engraved; there are also cf. Patton Engraved and cf. Womack Engraved vessels.

\section{REFERENCES CITED}

Benham, B. L., H. L. Miller, and J. V Sciscenti

1973 Archaeological Research in the Toledo Bend Reservoir. Archaeology Research Program, Southern Methodist University, Dallas.

Jensen, H. E.

1968a Coral Snake Mound (X16SA48). Bulletin of the Texas Archeological Society 39:9-44.

1968b Archaeological Investigations in the Toledo Bend Reservoir: 1966-1967. Archaeology Salvage Project, Southern Methodist University, Dallas.

McClurkan, B. B., W. T. Field, and J. N. Woodall

1966 Excavations in Toledo Bend Reservoir, 1964-65. Papers of the Texas Archeological Salvage Project No. 8. Texas Archeological Salvage Project, The University of Texas at Austin.

Perttula, T. K. and M. Walters

2015 Woodland and Caddo Period Sites at Toledo Bend Reservoir, Northwest Louisiana and East Texas. Journal of Northeast Texas Archaeology 56:19-124.

Reimer, P. J., E. Bard, A. Bayliss, J. W. Beck, P. G. Blackwell, C. B. Ramsey, C. E. Buck, H. Cheng, R. L. Edwards, M. Friedrich, P. M. Grootes, T. P. Guilderson, H. Haflidason, I. Hajdas, C. Hatte, T. J. Heaton, D. L. Hoffmann,

A. G. Hogg, K. A. Hughen, K. F. Kaiser, B. Kromer, S. W. Manning, M. Niu, R. W. Reimer, D. A. Richards, E.

M. Scott, J. R. Southon, R. A. Staff, C. S. M. Turney, and J. van der Plicht

2013 IntCal13 and Marine13 Radiocarbon Age Calibration Curves 0-50,000 Years Cal BP. Radiocarbon 55(4):1869-1887.

Scurlock, J. D.

1964 Archeological Reconnaissance at Toledo Bend Reservoir, 1962-1963 Season. Texas Archeological Salvage Project, The University of Texas at Austin. 
Scurlock, J. D. and W. A. Davis

1962 Appraisal of the Archeological Resources of Toledo Bend Reservoir, Panola, Newton, Sabine, and Shelby Counties, Texas; Sabine and DeSoto Parishes, Louisiana. Texas Archeological Salvage Project, The University of Texas at Austin.

Woodall, J. N.

1969 Archeological Excavations in the Toledo Bend Reservoir, 1966. Contributions in Anthropology No. 3. Department of Anthropology, Southern Methodist University, Dallas. 